\title{
PENGEMBANGAN TES KETERAMPILAN BERPIKIR KREATIF
}

\author{
I Wayan Redhana
}

\author{
Universitas Pendidikan Ganesha, Jln. Udayana No. 11 Singaraja \\ e-mail: redhana.undiksha@gmail.com
}

\begin{abstract}
The development of creative thinking skill test. The study was aimed to develop freecontent-creative thinking skill test used to measure students' creative thinking skills. To develop that test, research and development utilizing Borg and Gall model was conducted. Steps of the development in the study were conducted until preliminary testing. Findings of library study indicated that indicators or scales of creative thinking skills being used to design the creative thinking skills included fluency, originality, and flexibility. Findings of field study found that some teachers did not know if there were tests to measure students' creative thinking skills and they did not create the creative thinking skill test. The test being developed in the study consisted of 18 items. The preliminary testing produced one item needed to be revised and the remainings could be used. Reliability of test was very high with $r$ value of 0.880 .
\end{abstract}

Keywords: creative thinking, flexibility, fluency, originality, test

\begin{abstract}
Abstrak: Pengembangan Tes Keterampilan Berpikir Kreatif. Penelitian ini bertujuan mengembangkan tes keterampilan berpikir bebas konten yang dapat digunakan untuk mengukur keterampilan berpikir siswa. Untuk mengembangkan tes tersebut, penelitian dan pengembangan model Borg dan Gall dilakukan. Tahap pengembangan pada penelitian ini sampai pada tahap uji coba terbatas. Hasil-hasil studi pustaka menunjukkan bahwa indikator atau skala keterampilan berpikir kreatif yang digunakan untuk menyusun tes keterampilan berpikir kreatif meliputi kelancaran, keaslian, dan keluwesan. Hasil-hasil studi lapangan menemukan bahwa beberapa guru tidak mengetahui jika terdapat tes yang dapat mengukur kemampuan berpikir kreatif seseorang dan guru belum pernah membuat tes keterampilan berpikir kreatif. Tes keterampilan berpikir kreatif yang dikembangkan pada penelitian ini terdiri atas 18 butir soal. Uji coba terbatas tes menghasilkan satu butir soal direvisi, butir soal sisanya dapat dipakai. Reliabilitas tes sangat tinggi, yaitu dengan nilai $\mathrm{r}$ sebesar 0,880 .
\end{abstract}

Kata-kata Kunci: berpikir kreatif, keaslian, kelancaran, keluwesan, tes

Keterampilan berpikir tingkat tinggi sangat diperlukan oleh seseorang dalam menghadapi kehidupan yang sangat kompleks. Keterampilan berpikir tingkat tinggi ini meliputi keterampilan berpikir kritis, kreatif, pemecahan masalah, dan pembuatan keputusan. Hal ini disebabkan oleh dalam kehidupan seseorang sering dihadapkan pada pemecahan masalah dan pembuatan keputusan. Dalam pemecahan masalah dan pembuatan keputusan ini, keterampilan berpikir kritis dan kreatif diperlukan.

Penelitian tentang keterampilan berpikir kritis telah dilakukan oleh beberapa peneliti
(Redhana \& Liliasari, 2008a; Redhana\& Liliasari, 2008b; Redhana \& Liliasari, 2008c; Redhana \& Liliasari, 2008d; Redhana \& Merta, 2008; Redhana, 2009a; Redhana, 2009b; Redhana, 2010a; Redhana, 2010b; Redhana, 2011; Redhana, 2012). Sementara itu, beberapa instrumen keterampilan berpikir kritis standar sudah tersedia secara komersial, seperti Academic Profile, California Critical Thinking Skills Tests, College BASE, Collegiate Assessment of Academic Proficiency, Collegiate Learning Assessment Project, Tasks in Critical Thinking, Test of Everyday Reasoning, Watson Glaser Critical Thinking Apprai- 
sal, Community College Survey of Student Engagement, danHolistic Critical Thinking Scoring Rubric (Bers, 2005). Tes keterampilan berpikir kritis dengan konteks dan bahasa Indonesia baru dikembangkan oleh Sudria dan Redhana (2013).

Di lain pihak, penelitian yang berkaitan dengan pengembangan keterampilan berpikir kreatif siswa dalam pembelajaran masih belum banyak diteliti. Demikian juga, pengembangan tes keterampilan berpikir kreatif belum banyak dilakukan. Tes keterampilan berpikir kreatif yang telah dikembangkan oleh para ahli adalah antara lain Alternate Uses, Test of Divergent Thinking \& Creativity Test for Children (Guilford, 1987), dan Torrance Test of Creative Thinking (Torrance, dalam Kim, 2006). Sementara itu, tes keterampilan berpikir kreatif dalam konteks dan bahasaIndonesia belum banyak dikembangkan. Kalaupun ada, kebanyakan dari tes keterampilan berpikir kreatif dalam bahasa Indonesia ada dalam bentuk terjemahan dari tes berbahasa asing (Inggris).

Salah satu tujuan pembelajaran yang penting diukur dalam kurikulum nasional Indonesia adalah keterampilan berpikir kreatif. Oleh karena itu, pengembangan tes keterampilan berpikir kreatif menggunakan konteks dan bahasa Indonesia sangat penting dilakukan.

Keterampilan berpikir kreatif adalah keterampilan berpikir yang berkaitan dengan produksi ide-ide baru, cara-cara baru, solusi-solusi baru, metode-metode baru, dan prosedur-prosedur baru. Keterampilan berpikir kreatif ini berkaitan dengan pengembangan otak kanan, sedangkan keterampilan berpikir kritis berkaitan dengan pengembangan otak kiri (Verlinden, 2005).

Pentingnya pengembangan keterampilan berpikir tingkat tinggi, khususnya keterampilan berpikir kreatif telah menjadi tujuan pendidikan. Hal ini dapat dilihat dari tuntutan dalam kurikulum 2013. Kurkulum 2013 adalah kurikulum yang memberikan kesempatan kepada siswa untuk bertanya dan berpikir "nyeleneh."Bertanya dan berpikir "nyeleneh" ini sangat berkaitan dengan keterampilan berpikir kreatif.

Tujuan penelitian ini adalah memvalidasi dan mengembangkan tes keterampilan berpikir kreatif. Tes ini dapat digunakan untuk mengukur keterampilan berpikir kreatif siswa, terutama pada jenjang SMP ke atas. Hal ini didasari oleh teori yang dikemukakan oleh Piaget (dalam Slavin, 2006) bahwa siswa yang berusia 11 tahun ke atas sudah berada pada fase operasional formal. Pada fase operasional formal ini siswa sudah mampu berpikir kreatif.

\section{METODE}

Penelitian ini menggunakan model penelitian dan pengembangan pendidikan (Educational Research and Development). Penelitian dan pengembangan pendidikan adalah suatu proses untuk mengembangkan dan memvalidasi produkproduk pendidikan. Tahapan penelitian dan pengembangan pendidikan menurut Borg dan Gall (1983) meliputi tahap (1) penelitian dan pengumpulan informasi, (2) perencanaan, (3) pengembangan rancangan produk, (4) uji coba awal, (5) revisi produk utama, (6) uji coba utama, (7) revisi produk operasional, (8) uji coba operasional, (9) revisi produk akhir, dan (10) diseminasi dan implementasi. Pada penelitian dan pengembangan ini, kegiatan penelitian dilakukan sampai pada tahap uji terbatas dan revisi produk utama.

Populasi pada penelitian ini adalah siswa SMP di Kabupaten Buleleng Bali. Kegiatan yang dilakukan pada tahap penelitian dan pengumpulan data adalah studi pustaka dan studi lapangan. Studi lapangan dilakukan di 10 SMP yang ada di kabupaten Buleleng. Sementara itu, validasi dan uji keterbacaan tes masing-masing dilakukan oleh dua orang ahli dan lima orang siswa. Uji coba terbatas untuk mengetahui validitas dan reliabilitas tes dilakukan di salah satu SMP dengan melibatkan sekitar 45 orang siswa.

\section{Prosedur penelitian}

\section{Tahap Penelitian dan Pengumpulan Data}

Tahap penelitian dan pengumpulan data dilakukan melalui studi pustaka dan studi lapangan. Studi pustaka dilakukan dengan mengkaji dokumen-dokumen yang terkait. Kegiatan yang dilakukan pada studi pustaka adalah sebagai berikut.

a) Menganalisis tes-tes standar keterampilan berpikir kreatif.

b) Menganalisis skala dan subskala keterampilan berpikir kreatif dari tes standar.

c) Menganalisis teori-teori perkembangan kognitif siswa.

Data yang dikumpulkan dalam studi pustaka ini dilakukan melalui analisis dokumen.

Studi lapangan dilakukan untuk menelusuri pendapat guru tentang tes keterampilan berpikir kreatif, pembelajaran keterampilan kreatif, pe- 
ngalaman membuat tes keterampilan berpikir kreatif, dan manfaat dari implementasi tes keterampilan berpikir kreatif. Data yang dikumpulkan pada studi lapangan ini dilakukan dengan metode angket dan wawancara.

\section{Tahap perencanaan}

Kegiatan yang dilakukan pada tahap perencanaan adalah penentuan skala dan subskala untuk pembuatan draft tes keterampilan berpikir kreatif. Skala dan subkala ini diidentifikasi dari tes keterampilan berpikir kreatif standar.

Tahap pengembangan bentuk produk awal

Hasil-hasil yang diperoleh pada studi pustaka dan studi lapangan ini digunakan untuk merancang draft tes keterampilan berpikir kreatif. Draft tes ini siap divalidasi oleh ahli dan diuji keterbacaannya oleh siswa.

Tahap uji coba terbatas

Sebelum tes keterampilan berpikir kreatif diuji coba secara terbatas, draft tes ini divalidasi oleh dua orang ahli. Proses validasi ahli ini dilakukan melalui focus group discussion. Masukanmasukan yang diberikan oleh dua orang ahli digunakan untuk menyempurnakan draft tes yang dikembangkan. Tes ini selanjutnya diuji keterbacaan kepada lima orang siswa SMP. Uji keterbacaan ini juga dilakukan melalui focus group discussion yang didampingi oleh peneliti. Temuan-temuan pada uji keterbacaan ini digunakan untuk menyempurnakan draft tes yang dikembangkan.

Tes keterampilan berpikir kreatif yang telah divalidasi dan diuji keterbacaannya selanjutnya diuji coba secara terbatas di salah satu SMP yang ada di kabupaten Buleleng dengan melibatkan sebanyak 45 orang siswa. Hasil-hasil uji coba terbatas ini digunakan untuk menentukan validitas butir dan reliabilitas tes. Analisis butir tes menggunakan program SPSS 16.

Revisi produk utama

Hasil-hasil analisis butir pada uji coba terbatas menghasilkan validitas dan reliabilitas tes. Validitas dan reliabilitas tes ini digunakan untuk merevisi tes keterampilan berpikir kreatif yang dikembangkan.

\section{HASIL DAN PEMBAHASAN}

\section{Hasil}

Data hasil penelitian dan pengumpulan informasi

1) Studi pustaka
Studi pustaka dilakukan terhadap dokumen tertulis, seperti buku, laporan penelitian, dan artikel jurnal. Pada bagian ini, diuraikan beberapa teori tentang tes keterampilan berpikir yang dikembangkan oleh beberapa ahli, analisis Torrance Test of Creative Thinking Verbal (TTCTVerbal), dan analisis perkembangan kognitif siswa SMP yang dapat diuraikan sebagai berikut.

(a) Tes keterampilan berpikir kreatif yang dikembangkan oleh para ahli

Studi pustaka ini dilakukan untuk mengetahui beberapa tes keterampilan berpikir kreatif standar yang telah dikembangkan oleh para ahli. Hasil penelusuran melalui studi pustaka, ditemukan ada empat jenis tes keterampilan berpikir kreatif standar yang telah dikembangkan, yaitu: Alternate Uses, Test of Divergent Thinking, Creativity Test for Children (Guilford, 1987), Torrance Test of Creative Thinking (Torrance, dalam Kim, 2006), Creativity Assessment Packet (Williams, 1980), dan Tes Kreativitas Verbal (Munandar,1977).

(b) Analisis Torrance Test of Creative Thinking Verbal

Studi pustaka ini dilakukan untuk menganalisis tesketerampilan berpikir kreatif dari Torrance Test of Creative Thinking Verbal (TTCTVerbal). Tes ini dipilih karena tes ini cukup komprehensif mengukur keterampilan berpikir kreatif dan banyak digunakan oleh para peneliti di seluruh dunia. Berdasarkan analisis tersebut, dapat dirangkum beberapa skala keterampilan berpikir kreatif yang dapat dikembangkan. Skala keterampilan berpikir kreatif tersebut adalah kelancaran (fluency), keaslian (originality), dan keluwesan (flexibility).

(c) Analisis perkembangan kognitif siswa

Studi pustaka ini dilakukan untuk mengetahui perkembangan kognitif siswa SMP. Siswa SMP memiliki usia 11-15 tahun. Pada usia ini anak sudah dapat berpikir rasional. Hal ini sesuai dengan pendapat Piaget bahwa periode yang dimulai pada usia 11 tahun adalah periode yang kurang lebih sama dengan usia siswa SMP. Periode ini merupakan periode operasional formal. Tahap operasional formal, yang muncul pada usia 11-15 tahun, adalah tahap keempat dan terakhir dari tahap perkembangan kognitif Piaget (Slavin, 2006). Pada tahap ini, individu bergerak melampaui penalaran tentang pengalaman konkrit dan berpikir dengan cara yang lebih abstrak, idealis, dan logis. Berdasarkan analisis ini, dapat disimpulkan bahwa tes keterampilan berpikir 
kreatif yang dikembangkan dalam penelitian ini dapat diujikan pada jenjang SMP ke atas.

2) Data hasil studi lapangan

Studi lapangan dilakukan dengan menyebarkan angket untuk mengetahuipendapat guru terhadap tes keterampilan berpikir kreatif. Pada studi lapangan diperoleh beberapa temuan, yaitu guru-guru: (i) tidak mengetahui bahwa ada tes yang dapat mengukur kemampuan berpikir kreatif siswa, (ii) tidak memahami keterampilan berpikir kreatif, (iii) belum pernah membuat tes keterampilan berpikir kreatif, dan (iv) mengharapkan adanya tes keterampilan berpikir kreatif sehingga tes tersebut dapat mengukur keterampilan berpikir kreatif siswa.

\section{Hasil perencanaan}

Tes yang dikembangkan pada penelitian ini menggunakan skala dan subskala dari TTCTVerbal. Skala yang dimaksud adalah kelancaran, keaslian, dan keluwesan (Tabel 1). Skala dan subskala ini digunakan sebagai acuan dalam penyusunan tes keterampilan berpikir kreatif bebas konten.

\section{Hasil pengembangan rancangan produk}

Draft tes keterampilan berpikir kreatif yang dikembangkan pada penelitian ini berjumlah 18 butir soal uraian. Tes ini disusun berdasarkan skala dan subskala yang diuraikan dalam Tabel 1. Tes ini disusun dalam bentuk soal uraian dan dikerjakan dalam waktu 1 jam 20 menit.

Tabel 1. Skala dan Subskala yang Digunakan untuk Mengembangkan Tes Keterampilan Berpikir Kreatif

\begin{tabular}{ll}
\hline \multicolumn{1}{c}{ Skala } & \multicolumn{1}{c}{ Subskala } \\
\hline Kelancaran & $\begin{array}{l}\text { Tanya jawab: mengajukan } \\
\text { pertanyaan }\end{array}$ \\
\cline { 2 - 2 } & $\begin{array}{l}\text { Menebak: menebak penyebab dan } \\
\text { akibat }\end{array}$ \\
\cline { 2 - 2 } & $\begin{array}{l}\text { Pengandaian: pengandaian } \\
\text { keuntungan dan kerugian }\end{array}$ \\
\hline Keaslian & Pembaruan produk \\
\hline Keluwesan & Kegunaan yang tidak umum \\
\hline
\end{tabular}

\section{Data hasil validasi ahli}

Validitas instrumen merujuk pada kelayakan suatu instrumen untuk mengukur setiap aspek yang seharusnya dievaluasi. Validasi tes keterampilan berpikir kreatif melibatkan dua ahli yang keduanya merupakan dosen dari Jurusan Pendidikan Kimia Undiksha. Kedua ahli juga memberikan pertanyaan, kritik, dan saran yang digunakan untuk menyempurnakan rancangan tes yang dikembangkan. Kedua ahli memberikan penilaian terhadap tiga aspek, yaitu aspek materi, konstruksi, dan tata bahasa. Hasil-hasil validasi butir soal oleh ahli adalah(i) pada pertanyaan 1, gambar dianggap kurang jelas,(ii) pada pertanyaan 8 , kalimat "sebutkan tujuh kegunaan yang tidak umum dari tali" diganti dengan "sebutkan tujuh kegunaan yangtidak umum dari berbagai jenis tali," (c) pada pertanyaan 5, kalimat "Ideide tersebut dituangkan dalam beberapa kalimat, sebagai contoh, rambut kucing disemir dengan cat rambut berwarna hitam agar lebih seram, dan seterusnya" diganti dengan "ide dituangkan dalam beberapa kalimat, sebagai contoh, ban depan sepeda diganti dengan yang lebih kecil," dan sebagainya. Berdasarkan penilaian dan masukan yang diberikan oleh ahli, seluruh butir soal masuk dalam kategori terpakai dengan sedikit revisi pada aspek bahasanya. Selain memberikan penilaian terkait butir soal, kedua ahli juga memberikan penilaian pada pedoman penskoran. Hal ini dilakukan karena jenis soal yang dikembangkan adalah jenis soal uraian. Hasil validasi pedoman penskoran adalah(i) pada pertanyaan 1, 2, dan 3, kalimat"untuk pertanyaan-pertanyaan yang relevan dengan gambar lebih dari 9 butir" diganti dengan "untuk lebih dari 9 butir pertanyaan yang relevan dengan gambar," (ii) pada pertanyaan 9 dan 10, kalimat "untuk gagasan-gagasan yang baru, unik, dan relevan dengan gambar dengan jumlah lebih dari 9 butir" diganti dengan "untuk gagasan-gagasan yang baru, unik, dan relevan dengan ilustrasi gambar dengan jumlah lebih dari 9 butir," dan sebagainya. Berdasarkan penilaian dan masukan yang diberikan oleh kedua ahli, pedoman penilaian tersebut direvisi pada aspek pengategorian skor, redaksi kalimat, dan beberapa kesalahan penulisan. Kalimat yang direvisiantara lain "untuk pertanyaan-pertanyaan yang relevan dengan gambar lebih dari 9 butir" menjadi "untuk lebih dari 9 butir pertanyaan yang relevan dengan gambar," urutan pengategorian skor dari " $0,1,3,5$ " menjadi " $0,1,2,3$ ", kalimat "soal sesuai perkembangan kognitif siswa" menjadi "soal sesuai dengan perkembangan kognitif siswa," dan kalimat "sebutkan tujuh kegunaan yang tidak umum dari tali" menjadi "sebutkan tujuh kegunaan yang tidak umum dari berbagai jenis tali." Seluruh permasalahan tersebut direvisi sebelum dilakukan uji keterbacaan.

\section{Data hasil uji keterbacaan}

Uji keterbacaan dilakukan melalui focus group discussion yang dilakukan bersama lima orang siswa dari SMP Laboratorium Undiksha, Singaraja. Metode ini dipilih untuk memudahkan menemukan permasalahan pada setiap butir soal. Pada uji keterbacaan ini, kelima siswa ini di- 
minta membaca 18 butir soal dan memberikan pertanyaan, kritik, dan saran terkait keterbacaan butir soal. Kemudian soal dibahas satu persatu untuk menemukan pemahaman siswa terhadap butir soal. Hasil uji keterbacaan ini adalah digantinya beberapa kata agar soal mudah dipahami. Kata "kemukakan" pada soal nomor 2, 3, 5,6 , dan 8 diganti dengan kata "sebutkan." Selain itu, siswa juga diminta memberikan kritik dan saran. Kritik yang diberikan adalah jumlah jawaban yang diminta terlalu banyak. Pada akhir kegiatan, siswa juga diminta menjawab soal-soal tersebut guna memastikan bahwa tidak terdapat kesalahan pemahaman pada setiap butir soal.

Data hasil uji coba terbatas

2) Validitas butir soal

Tes keterampilan berpikir kreatif yang diujicobakan pada uji coba terbatas berjumlah 18 butir soal. Tes ini diujicobakan di dua kelas, yaitukelas VIII 1 dan VIII 2 SMP Laboratorium Undiksha Singaraja. Jumlah total siswa dari kedua kelas yang dijadikan subjek uji coba terbatas adalah 45 siswa. Nilai korelasi tiap butir soal pada uji coba terbatas dapat dilihat pada Tabel 2.

Dari hasil analisis validitas butir Tabel 2 didapat nilai korelasi antara skor butir dengan skor total. Nilai ini kemudian dibandingkan dengan nilai $r$ tabel. $R$ tabel dicari pada taraf signifikansi 0,05 (5\%) dengan uji 2 sisi dan jumlah data 45. Dengan demikian, nilai $r$ tabel yang diperoleh sebesar 0,294. Berdasarkan hasil analisis validitas butir soal, 17 butir soal memenuhi kriteria valid, sedangkan satu butir soal perlu direvisi, yaitu butir soal nomor 5 terutama dari redaksinya.

2) Reliabilitas tes keterampilan berpikir kreatif

Reliabilitas berhubungan dengan masalah kepercayaan. Suatu tes dikatakan memiliki taraf kepercayaan yang tinggi jika tes tersebut dapat memberikan hasil yang tetap. Berdasarkan hasil analisis reliabilitas tes menggunakan program SPSS 16.0, tes keterampilan berpikir kreatif tersebut memiliki nilai $r$ sebesar 0,880 sehingga dapat disimpulkan bahwa tes keterampilan berpikir kreatif yang dikembangkan memiliki derajat reliabilitas yang sangat tinggi. Selain itu, tujuan uji coba terbatas adalah untuk menemukan kendalakendala yang dihadapi dalam mengimplementasikan tes dan mengevaluasi kecukupan alokasi waktu pengerjaan tes.

Berikut ini disajikan beberapa contoh butir soal keterampilan berpikir kreatif yang dikembangkan pada penelitian ini. Butir soal nomor 1 dengan skala"Kelancaran/mengajukan pertanya- an, menebak penyebab, dan menebak akibat (Gambar 1)" adalah:

Pada Gambar 1, terlihat sebidang lahan yang kering dan tandus. Beberapa pohon terlihat tidak berdaun dan beberapa batang tanaman terlihat telah ditebang.

Tabel 2.Hasil Uji Validitas Butir Soal pada Uji Coba Terbatas

\begin{tabular}{|c|c|c|c|}
\hline \multirow[t]{2}{*}{$\begin{array}{l}\text { No. } \\
\text { Soal }\end{array}$} & \multicolumn{2}{|c|}{$\begin{array}{c}\text { Validitas butir soal } \\
\left(\mathrm{N}=45, \alpha=5 \%, \mathrm{r}_{\text {tabel }}=\right. \\
0,294)\end{array}$} & \multirow[t]{2}{*}{ Keputusan } \\
\hline & Korelasi & Kriteria & \\
\hline $1 \mathrm{a}$ & 0,603 & $\begin{array}{l}\text { Validitas } \\
\text { Tinggi }\end{array}$ & Dipakai \\
\hline $1 b$ & 0,611 & $\begin{array}{l}\text { Validitas } \\
\text { Tinggi }\end{array}$ & Dipakai \\
\hline $1 \mathrm{c}$ & 0,599 & $\begin{array}{l}\text { Validitas } \\
\text { Sedang }\end{array}$ & Dipakai \\
\hline $2 \mathrm{a}$ & 0,588 & $\begin{array}{l}\text { Validitas } \\
\text { Sedang }\end{array}$ & Dipakai \\
\hline $2 b$ & 0,735 & $\begin{array}{l}\text { Validitas } \\
\text { Tinggi }\end{array}$ & Dipakai \\
\hline $2 \mathrm{c}$ & 0,735 & $\begin{array}{l}\text { Validitas } \\
\text { Tinggi }\end{array}$ & Dipakai \\
\hline $3 a$ & 0,709 & $\begin{array}{l}\text { Validitas } \\
\text { Tinggi }\end{array}$ & Dipakai \\
\hline $3 b$ & 0,540 & $\begin{array}{l}\text { Validitas } \\
\text { Sedang }\end{array}$ & Dipakai \\
\hline $3 c$ & 0,553 & $\begin{array}{l}\text { Validitas } \\
\text { Sedang }\end{array}$ & Dipakai \\
\hline 4 & 0,399 & $\begin{array}{l}\text { Validitas } \\
\text { Rendah }\end{array}$ & Dipakai \\
\hline 5 & 0,171 & $\begin{array}{l}\text { Validitas } \\
\text { Sangat } \\
\text { Rendah }\end{array}$ & Direvisi \\
\hline 6 & 0,565 & $\begin{array}{l}\text { Validitas } \\
\text { Sedang }\end{array}$ & Dipakai \\
\hline 7 & 0,540 & $\begin{array}{l}\text { Validitas } \\
\text { Sedang }\end{array}$ & Dipakai \\
\hline 8 & 0,537 & $\begin{array}{l}\text { Validitas } \\
\text { Sedang }\end{array}$ & Dipakai \\
\hline $9 \mathrm{a}$ & 0,617 & $\begin{array}{l}\text { Validitas } \\
\text { Tinggi }\end{array}$ & Dipakai \\
\hline $9 b$ & 0,702 & $\begin{array}{l}\text { Validitas } \\
\text { Tinggi }\end{array}$ & Dipakai \\
\hline $10 \mathrm{a}$ & 0,569 & $\begin{array}{l}\text { Validitas } \\
\text { Sedang }\end{array}$ & Dipakai \\
\hline $10 \mathrm{~b}$ & 0,583 & $\begin{array}{l}\text { Validitas } \\
\text { Sedang }\end{array}$ & Dipakai \\
\hline
\end{tabular}

a. Buatlah minimal sembilan pertanyaan tentang kondisi pada gambar di atas!

b. Kemukakan minimal sembilan hal yang menyebabkan kondisi seperti pada gambar di atas!

c. Kemukakan minimal sembilan akibat yang ditimbulkan oleh kondisi pada gambar di atas! 


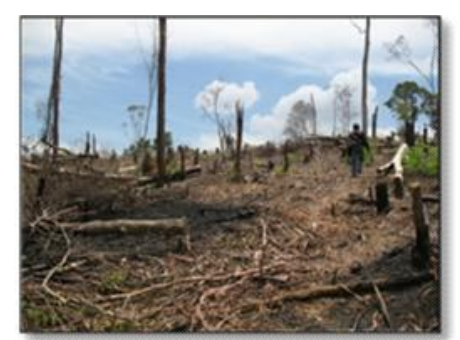

Gambar 1. Hutan Gundul

Sementara itu, butir soal nomor 5 dengan skala"Keaslian/pembaruan produk" (Gambar 2) adalah:

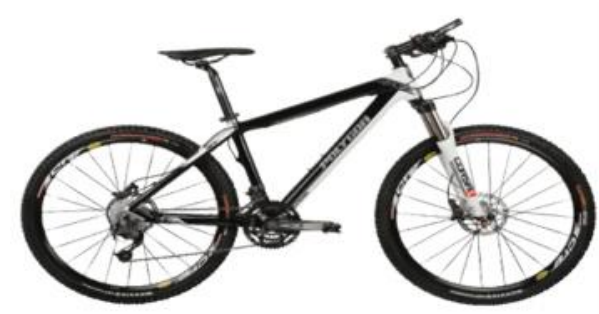

Gambar 2. Sepeda Gunung

Sepeda merupakan salah satu alat transportasi yang biasa digunakan oleh masyarakat. Pada beberapa kesempatan seperti pada saat peringatan Hari Kemerdekaan Republik Indonesia, beberapa pihak mengadakan lomba sepeda hias. Berikan sembilan ide-ide kreatif untuk membuat sepeda pada gambar di atas terlihat lebih menarik. Ide dituangkan dalam beberapa kalimat, sebagai contoh, ban depan sepeda diganti dengan yang lebih kecil.

Berikutnya adalah butir soal nomor 8 dengan "Kelenturan/kegunaan yang tidak umum." Tali merupakan benda yang kecil dan panjang. Pada umumnya, tali digunakan untuk mengikat benda, alat bantu untuk menarik sesuatu, menaikkan layang-layang, dan sebagainya. Sebutkan tujuh kegunaan yang tidak umum dari tali!

\section{Pembahasan}

Semua kurikulum pendidikan yang diterapkan di seluruh dunia, termasuk di Indonesia, menuntut pengembangan keterampilan berpikir kreatif siswa. Pengembangan keterampilan berpikir kreatif ini sangat penting dilakukan agar siswa mampu menghasilkan ide-ide baru, cara-cara baru, metode-metode baru, prosedur-prosedur baru, dan pengalaman-pengalaman baru. Ini akan mendorong berkembangnya produk sains, misalnya teknologi. Alat transportasi dari sepeda sampai pesawat udara merupakan hasil dari keterampilan berpikir kreatif. Demikian juga alat komunikasi dari telepon kabel sampai telepon seluler merupakan hasil pemikiran kreatif manusia. Perkembangan dari mesin ketik sampai komputer super canggih sekarang ini juga merupakan hasil pemikiran kreatif manusia. Oleh karena itu, sangat masuk akal jika kurikulum pendidikan yang diberlakukan selalu menekankan pada upaya pengembangan keterampilan berpikir kreatif peserta didik.

Tuntutan pengembangan keterampilan berpikir kreatif siswa di sekolah harus diikuti oleh penyediaan alat ukur standar yang valid untuk mengukur keterampilan berpikir kreatif siswa. Keterampilan berpikir kreatif tidak dapat diukur dengan sembarang tes. Dengan kata lain, tes harus sengaja dibuat untuk mengukur keterampilan berpikir kreatif siswa.

Kehadiran tes keterampilan berpikir kreatif pada penelitian ini akan membantu guru-guru di lapangan dalam mengukur keterampilan berpikir kreatif siswa. Hasil-hasil penelitian menunjukkan bahwa tes keterampilan berpikir kreatif yang dikembangkan pada penelitian ini memiliki validitas cukup baik. Dari 18 butir soal, 17 soal memenuhi kriteria valid, sedangkan satu butir soal termasuk kriteria kurang valid. Untuk itu, butir soal ini direvisi yang menyangkut redaksinya. Hal ini disebabkan oleh seluruh butir soal masih akan diuji coba pada skala luas dengan melibatkan jumlah subjek yang lebih banyak. Di lain pihak, reliabilitas tes yang dikembangkan pada penelitian ini tergolong sangat tinggi, dengan nilai $r$ sebesar 0,880 . Artinya, walaupun tes ini baru pada tahap uji coba terbatas, tes ini sudah dapat digunakan untuk mengukur keterampilan berpikir kreatif siswa.

Berikut ini disajikan analisis terhadap butir soal nomor 1 yang berkaitan dengan "Kelancaran/mengajukan pertanyaan, menebak penyebab, dan menebak akibat." Terhadap pertanyaan (a), beberapa jawaban yang dapat diterima adalah apa fungsi hutan, apa yang menyebabkan hutan bisa gundul, siapa/apa yang menyebabkan hutan gundul, apakah hutan yang telah gundul dapat berfungsi dengan baik, apakah hewan-hewan dapat hidup di hutan yang gundul, apakah hutan yang gundul dapat menyimpan air, bagaimana cuaca di hutan yang gundul, seberapa parah kerusakan hutan jika pohonnya di tebang sambarangan, dan untuk apa orang menebang pohon secara sembarangan. Terhadap pertanyaan (b) beberapa jawaban yang dapat diterima adalah pembukaan lahan untuk sawah, pembukaan lahan untuk pemukiman penduduk, pembukaan lahan un- 
tuk tanaman industri, pembukaan lahan untuk kegiatan industri, pengambilan kayu besar-besaran tanpa diikuti reboisasi, pengambilan sumber bahan tambang dari dalam tanah, pengambilan batu bata, terjadinya tanah longsor di hutan, dan terjadinya banjir. Terhadap pertanyaan (c), beberapa jawaban yang dapat diterima adalah ter-ganggunya ekosistem, terjadinya perubahan iklim, terjadinya pemanasan global, berkurangnya pasokan oksigen dunia, berkurangnya persediaan air atau terjadi kekeringan, punahnya flora dan fauna, punahnya tanaman-tanaman penting, misalnya tanaman yang menghasilkan obat-obatan, terjadinya banjir karena sedikit tanaman yang menyimpan air, dan cepat habisnya persediaan kayu untuk pembuatan barang-barang dari kayu.

Siswa yang tidak dapat berpikir dengan lancar tidak mungkin dapat menghasilkan jumlah jawaban yang banyak, dalam hal ini sembilan. Umumnya, siswa hanya mampu menjawab pertanyaan ini dengan 3-4 jawaban. Ini menunjukkan siswa belum berpikir dengan lancar.

Berikut ini disajikan analisis butir soal nomor 5 yang berkaitan dengan "Keaslian/pembaruan produk." Beberapa jawaban siswa yang dapat diterima adalah sepeda dibuatkan pakaian, sepeda diberi hiasan bunga di bagian depan, ban belakang sepeda dibuat lebih kecil, ruji ban sepeda dibuat lebih besar, sadel sepeda dibuat lebih besar dan posisinya lebih pendek, stang sepeda dibuat posisinya lebih tinggi, stang sepeda dibuat bentuknya ke atas, pedal sepeda dibuat lebih besar, rem sepeda dibuat dari rem cakram, badan sepeda dicat berwarna-warni, sepeda ditambah lampu di bagian depan dan belakang, di bagian belakang sadel sepeda ditempatkan keranjang, dan dibagian depan sepeda diisi terompet. Umumnya, siswa dapat menghasilkan 5-6 jawaban untuk pertanyaan ini.

\section{DAFTAR RUJUKAN}

Bers, T. 2005. Assessing Critical Thinking in Community Colleges.New Directions for Community Colleges.130: 15-25.

Borg, W. R. \& Gall, M. D. 1983.Educational Research: An introduction. $4^{\text {th }}$ Ed. New York: Longman, Inc.

Guilford, J. P. 1987. Creativity Reasearch: Past, Present and Future. Dalam Isaksen (Ed.) Frontier of Creativity Research. (hal. 3365). Buffalo, NY: Bearly.
Berikut disajikan analisis butir soal nomor 8 untuk "Kelenturan/kegunaan yang tidak umum." Beberapa jawaban siswa yang dapat diterima adalah tali digunakan untuk gantung diri, mena-rik pesawat udara yang mogok, mengikat mesin mobil, menarik ikan di laut, membuat sumbu kompor, membuat anyaman, membuat lukisan, dan melukis sebagai pengganti kuas.

\section{SIMPULAN}

Tes keterampilan berpikir kreatif yang dikembangkan pada penelitian ini menggunakan tiga skala yang diturunkan dari Torrance Test of Creative Thinking Verbal tersebut adalah kelancaran, keaslian, dan keluwesan. Skala kelancaran dijabarkan menjadi subskala tanyajawab, menebak, dan pengandaian, skala keaslian menjadi subkala pembaruan produk, dan skala keluwesan menjadi subskala kegunaan yang tidak umum. Subskala tanya jawab dijabarkan menjadi aktivitas mengajukan pertanyaan, subskala menebak menjadi aktivitas menebak penyebab dan akibat, dan subskala pengandaian dijabarkan menjadi aktivitas pengandaian keuntungan dan kerugian.

Berdasarkan dan sub ini, jumlah soal yang dikembangkan sebanyak 18 butir. Untuk menentukan validitas butir soal dan realibitas tes, uji coba terbatas dilakukan. Hasil uji coba terbatas menunjukkan bahwa 17 butir soal tergolong valid dan satu butir soal kurang valid. Terhadap butir soal yang kurang valid ini dilakukan revisi yang menyangkut redaksinya. Sementara itu, reliabilitas tes tergolong sangat tinggi, yaitu dengan nilai $r$ sebesar 0,880 .

Kim, K. H. 2006. Can We Trust Creativity Test? A Review of the Torrance Test of Creative Thinking (TTCT). Creativity Research Journal, 18(1): 3-14.

Munandar, S. C. 1977. Creativity and Education: A Study of the Relationship between Measures of Creative Thinking and a Number of Educational Variables in Indonesian Primary and Junior Secondary Schools. Jakarta: Universitas Indonesia. 
Redhana, I W. \& Liliasari.2008a. Program Pembelajaran Keterampilan Berpikir Kritis pada Topik Laju Reaksi untuk Siswa SMA. Forum Kependidikan, 27(2): 103112.

Redhana, I W. \& Liliasari.2008b. Efektivitas Program Pembelajaran Keterampilan Berpikir Kritis pada Topik Termokimia.Prosiding Seminar Nasional Kimia dan Pendidikan Kimia.Universitas Negeri Surakarta. Surakarta. 22 November.

Redhana, I W. \& Liliasari.2008c. Peningkatan Keterampilan Berpikir Kritis Siswa melalui Program Pembelajaran Berbasis Masalah Terbimbing pada Topik Termokimia. Prosiding Seminar Nasional Pendidikan. Universitas Lampung. Bandar Lampung. 24 Januari.

Redhana, I W. \& Liliasari. 2008d. Program for Critical Thinking Skill teaching and learning: Excellences and problems. Proceedings The $2^{\text {nd }}$ International Seminar on Science Education.Indonesia University of Education. Bandung. October $18^{\text {th }}$.

Redhana, I W. \& Merta, L. M. 2008.Pertanyaan Socratik untuk meningkatkan keterampilan berpikir kritis siswa. Prosiding Seminar Nasional Kimia dan Pendidikan Kimia IV.Universitas Pendidikan Indonesia.Bandung.9 Agustus.

Redhana, I W. 2009a.Pengembangan Perangkat Pembelajaran Berbasis Masalah dan Pertanyaan Socratik untuk Meningkatkan Keterampilan Berpikir Kritis Siswa SMP.Jurnal Pendidikan dan Pengajaran, 42(3): 151-159.

Redhana, I W. 2009b.Application of Argument Mapping-Based Learning Model to Improve Students' Critical Thinking Skills in Thermochemistry Topic. Proceedings The $3^{\text {rd }}$ International Seminar on Science Edu- cation. Indonesia University of Education. Bandung. October $17^{\text {th }}$.

Redhana, I W. 2010a.Pengaruh Model Pembelajaran Berbasis Peta Argumen terhadap Keterampilan Berpikir Kritis Siswa pada Topik Laju Reaksi.Jurnal Pendidikan dan Pengajaran, 43(2): 141-148.

Redhana, I W. 2010b.The Development of Argument-Map-Based-chemistry Work-book of Themochemistry Topic. Procee-dings The $4^{\text {rd }}$ Internasional Seminar in Science Education.Indonesia University of Education. Bandung. October $30^{\text {th }}$.

Redhana, I W. 2011.Buku Kerja Kimia Berbasis Peta Argumen untuk Meningkatkan Keterampilan Berpikir Kritis Siswa.Jurnal Pendidikan Kimia Indonesia, 1(1): 18-27.

Redhana, I W. 2012. Model Pembelajaran Berbasis masalah dan pertanyaan Socratik untuk Meningkatkan Keterampilan Berpikir Kritis Siswa. Cakrawala Pendidikan, XXXI (3): 351-365.

Slavin, R. E. 2006. Educational Psychology: Theory and Practice. ( $8^{\text {th }}$ Ed.). Boston: Pearson Education, Inc.

Slavin, R. E. 2006.Educational Psychology: Theory and Practice. ( $8^{\text {th }}$ Ed.). Boston: Pearson Education, Inc.

Sudria, I B. N. \& Redhana, I W. 2013. Pengembangan Tes Keterampilan Berpikir Kritis. Makalah disajikan pada Seminar Nasional Riset Inovatif I yang diselenggarakan oleh Lembaga Penelitian Universitas Pendidikan Ganesha, 21-22 November.

Verlinden, J. 2005. Critical Thinking and Everyday Argument. Belmont, CA: Wadsworth/ Thomson Learning, Inc

Williams, F. 1980. Creativity Assessment Packet. Buffalo, NY: DOK. 